\title{
Determinants of foreign direct investment in Tunisia: Empirical assessment based on an application of the autoregressive distributed Lag model
}

\section{Teheni El Ghak *, Abdelkader Zribi **, Nadia Zrelli ***, Hazar Temmi $* * * *$}

* University of Tunis El Manar,

Post box 248 - 2092 Tunis El Manar II, Tunisia

Laboratory of International Economic Integration, Faculty of Economic Sciences and Management of Tunis

** Tunis Business School,

PO. Box $n^{\circ}$ 65, Bir El Kassaa 2059, Tunisia

*** University of Tunis,

4, Rue Abou Zakaria El Hafsi, Montfleury, 1089 Tunis, Tunisia

DEFI ESSECT

**** University of Tunis El Manar,

Post box 248 - 2092 Tunis El Manar II, Tunisia

Laboratory of International Economic Integration, Faculty of Economic Sciences and Management of Tunis

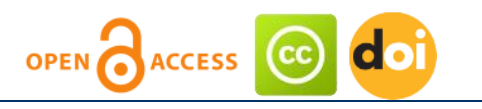

Article history:

Received: March 14, 2017

1st Revision: April 26,

2017

Accepted: April 30, 2017

JEL classification:

E22

F21

G11

DOI:

10.14254/jems.2017.2-1.4

\begin{abstract}
In recent years, the changing economic and political environment in Tunisia led to a renewed interest on the drivers of foreign direct investment, given its potential important gains. In this study, we investigated the impact of various factors over the period 1980-2012. In doing this, three categories of determinants were considered: economic, political and sociocultural variables. Empirical findings drawn from the autoregressive distributed lag bounds testing approach show that variation in foreign direct investment inflow in the short-run and long-run is affected by the majority of variables considered, except exchange rate, urban population and gross domestic savings. As a matter of policy, it is essential that government should continue its efforts to create a macroeconomic environment which is attractive to foreign direct investment.
\end{abstract}

Keywords: foreign direct investment, autoregressive distributed lag approach, cointegration, Tunisia. 


\section{Introduction}

It is well known theoretically and practically that foreign direct investment (FDI) enhances employment, technology transfer and productivity which ultimately promote economic growth (De Mello, 2007). In this regard, the question about factors that may influence FDI has a high economic and societal importance for nations. The identification of such determinants - in order to help governments to formulate and execute appropriate reforms - has received significant attention in both theoretical and empirical studies all over the world. Different types of factors ranging from purely economic indicators (market size, financial development,...) to legal and political factors (governance, type of the political regime,...) were identified. The choice of variables is generally based on formal hypotheses or theories of FDI or is made intuitively (Moosa, 2002). However, divergent views have emerged concerning the appearance and sign of the relationship. The FDI theories can be classified generally into two groups. At the micro-level, there are theories like capital market theory (Heckscher-Ohlin, 1933; MacDougall, 1960; Kemp, 1964) (Faeth, 2009, pp. 167), eclectic paradigm (Dunning, 1986-1988), market imperfections (Hymer, 1976; Kindleberger, 1969), behaviour theory (Aharoni, 1966), oligopoliy market (Knickerbocker, 1973), Product differentiation (Caves, 1971) and theory of internalization (Kindleberger, 1969; Caves, 1971). Life cycle theory (Vernon, 1966) combines both the micro level and macro-level FDI theories. At the macro-level, we have international trade approach (Smith, 1776; Ricardo, 1817) and institutional analysis (Wilhelms, 1998; Francis et al. 2009; Peng 2009; Faeth, 2009).

In seeking to understand the determinants of FDI, empirical studies have used different types of econometric approaches and a variety of indicators (Blonigen, 2005). The results are often mixed and inconclusive. Several critics were highlighted by authors. For instance, according to Chakrabarti (2001), empirical results are fairly fragile statistically. Despite the enormous body of studies, Blonigen (2005, pp. 29) argued that the empirical literature on determinants of FDI is still at early stages that most hypotheses are still up for grabs. Thus, the issue still attracts both academia and policy-makers to advance the knowledge in this area.

Tunisia has never been a major recipient of FDI flows; regardless of the policies the country pursues (Government has implemented reform packages aiming, among other objectives, at attracting more inflows. Foreign investment for example is regulated by Investment Code (Law 1993-120) which was last amended on January 26, 2009. In order to further strengthen the investment climate, a review of the Investment Code is slated for next few years. In fact, FDI inflows followed an irregular path. It has known its peak in 2006 with $9.62 \%$ and $6.16 \%$ in 2008 . Afterwards, FIDI inflows declined (due to the global economic crisis), which was further accentuated in 2011 because of the revolution. The lowest rate witnessed by Tunisia was $0.65 \%$ in 1990. Tunisia maintained an average stock of FDI close to $54.84 \%$ during the studied period, reaching an all time high of $74.02 \%$ in 2012 and a record low of $34.64 \%$ in 1980 . CIA world factbook ranks Tunisia 59th out of the 105 countries rated according to the level of accumulated FDI (US dollars). We may say that the country have attracted considerably less FDI relative to its size. The manifestation of revolution in the late 2010s and early 2011s made the authority to change their attention among others toward the attractiveness of his territory: increasing effort toward attracting foreign direct investment becomes a key government priority.

Against this background, this paper attempts to respond to the question:

What macroeconomic factors matter as determinants of FDI inflow in Tunisia?

In line with earlier studies, our paper takes a close look at how robust is the relationship between FDI and its determinants, but with some differences. Previous studies generally considered MENA and south Mediterranean countries including Tunisia (Kamaly, 2002; Onyeiwu, 2003-2008; Van Wyk, 2010; Sekkat \& Veganzones-Varoudakis, 2004; Méon \& Sekkat, 2004; Hisarciklilar et al. 2006; Shirazy, 2010; Eltayeb \& Sidiropoulos, 2010; Jabri et al., 2013). With respect to the case of Tunisia, studies that tried to investigate the determinants of FDI inflows are very few (Lahimar, 2006; Driss, 2007; Karry \& Toumi, 2007; Toumi, 2009). This means that the question remains unresolved. In our view, the focus on Tunisia is problematic due to the lake of a long series database, the lack of data on some variables, the quality of data,...The analyses of the authors are based generally on the gravity model or a cross-section and panel regression or questionnaires. In this paper, in order to examine the existence of a long-run equilibrium relationship between the variables of interest, we apply the autoregressive distributed lag (ARDL) bounds testing approach, developed by Pesaran et al. (2001).

The paper is organized as follows. Section II describes the dataset. Section III presents the econometric method used in this paper. We summarize the results in section IV. Section V concludes the study. Some policy conclusions are drawn and directions for future research in this area are suggested. 


\section{Data description}

The data for the study are time series data covering the period 1980 to 2012 . We consider 1980 as our starting point because data on the major variables of interest prior to that date are very poor.

The description and source of all variables of interest is presented in Table 1. Following standard practice, we use FDI inflow as a percentage of GDP to measure foreign direct investment. According to Faeth (2009), a combination of factors from different theoretical models could explain FDI. Given the objective of the study, we focus on the location dimension of the OLI paradigm, the new trade theory and the institutional approach.

GDP per capita is included to capture the level of development. Tunisia is a small country both in terms of population and GDP per capita. The country experienced a deceleration of the population growth rate which went from $2.67 \%$ in 1980 (6.38 Million according to 1980 estimates) to $0.98 \%$ in 2012 (10.62 Million according to 2012 estimates). The World Bank (2012) ranks Tunisia 91th out of the 185 countries rated according to GDP per capita (purchasing power parity, US dollars). It seems that Tunisia is not considered to be a big market and the purchasing power of the population is not big either. In terms of Tunisian's market size development, the country is not among the best performers. The World Bank (2013) ranks Tunisia 74th out of the 195 countries rated according to GDP (purchasing power parity, US dollars). Tunisia's economic performance has fluctuated since 1980. Over the period 1980-2012, the real average GDP annual growth was in the range of $4.23 \%$, reaching an all time high of $7.95 \%$ in 1990. From 1980-1988, economic growth was volatile and the weaker growth performance was observed. From 1989 onwards, economic growth was relatively more stable. The structural adjustment program launched since 1986 seem to have produced positive impacts few years later. The economic growth rates have become positive and were higher than 5\% in 1990, 1992, 1996, 2004 and 2007. In the context of a political and security crisis, Tunisia registered a record low of $-0.23 \%$ in 2011 , down from the 2010 level (3.6\%). The recovery of the Tunisian economy remains timid, with a real growth rate estimated at $4.09 \%$ in 2012 and $2.80 \%$ in 2013.

Foreign direct investment stocks are introduced to test whether agglomeration has an effect on FDI inflows.

We also collect data on the gross domestic savings (\% of GDP) which can be indicative of the dependence on foreign capital. The national economy accuses a declining rate of domestic saving to gross domestic product during 2009-2012. It was last measured at $15.13 \%$ in 2012.

To account for the role of debt, we consider the External debt stocks as a share of GNI. It is the main component of external finance mobilized by Tunisian authorities (an average amount of $59.04 \%$ of GNI).

The degree of openness is taken into account to express the level of global integration of Tunisia. It is the sum of exports and imports in GDP. Since 1986, numerous measures have been taken towards liberalization of trade to facilitate the entry of foreign investors (The structural adjustment plan (1986), adherence to the GATT (1989), adherence to the WTO (1994), the ratification of a free-trade agreement with the European Union (1995),.... ). The country started a trade liberalization program - gradual abolishment of barriers to trade (Cherkaoui \& Naini, 2002, pp. 6) - and the economy started working based on market principles. It is clear that the indicator of foreign trade has increased, exceeding $100 \%$ during the last three years. Nevertheless, it is interesting to note that the import of goods and services constituted generally the larger part of the trade flows (Tunisia Imports of Goods and Services is at 45.6\% of GDP in 1980 and 58.33\% of GDP in 2012, compared to 40.23\% in 1980 and 49.15\% of GDP in 2012 for Tunisia exports of Goods and Services). This resulted in relatively large trade deficits.

Inflation rate as measured by consumer prices (Percent change) is used as a proxy for economic stability reflecting the presence of internal economic pressures or inability to restrict money supply. Inflation rate in Tunisia has constantly moved during the study period. It averaged $5.47 \%$ from 1980 until 2012, reaching an all time high of $13.76 \%$ in 1982 and a record low of $1.44 \%$ in 2005 . In the early 1980s, problems with economic performance started to emerge: the rate of inflation exceeded a reasonable level of $3 \%$. The 1990s, Tunisia started a series of economic policies, part of a general structural adjustment plan partly prescribed by the International Monetary Fund in 1986. These measures caused a growing inflationary pressure in the country (peaks during the years 1991 and 1995). During 2000 and 2005, price levels were kept under control (not exceeding a reasonable level of $3 \%$ ). In the period 2006-2012, the inflation rate began once again trending upward albeit in a cyclical fashion. In 2012, inflation rate reached 5.56\% against $3.54 \%$ in 2011. According to the latest figures from the IMF, the inflation rate was recorded at $6.1 \%$ in 2013, the highest for 8 years. These pressures occurred in the aftermath of the economic slowdown resulting from the revolution and against a backdrop of social demands. 
Another measure of macroeconomic uncertainty is exchange rate volatility measured as the change in log of real effective exchange rate index $(2005=100)$. It is defined as the nominal effective exchange rate adjusted for relative movements in national price indicators of a home country and selected countries. The gradual liberalization of Tunisia's trade was complemented by a progressive change in the foreign exchange rate policies. In fact, by August 1986, the Tunisian dinar was devalued to preserve external competitiveness, within the framework of a marketoriented reform process. As a result, the national currency was devalued by about $40 \%$ over the next few years. Afterwards, Tunisia pegged its currency to a basket of currencies and classified its regime as a managed float until 1994 (a crawling peg country according to the IMF (2004)). From 2005 until 2007, the exchange rate regime was a managed float regime, with no predetermined trajectory for the exchange rate coupled with a monetary aggregate target. For 2008, the IMF reclassified Tunisia as a crawling peg country with a monetary aggregate target. In 2012, the Tunisian exchange rate regime was classified as crawling peg (IMF, 2012). Figure 13 confirms the exchange rate policies mentioned above. Tunisian RER depreciated steadily for most of the period studied. Particularly large declines occurred during 1985-1988. We note a real appreciation at the beginning of the 1990s, a depreciation in 1993, a gradual appreciation which stabilizes during the late 1990s and a depreciation after 1999 (Fanizza et al., 2002).

The ratio of Money and quasi money (M2) as \% of GDP is used to measure the financial depth in Tunisia. The financial development is proxied by the ratio of bank sector's credit to private sector to GDP. Since 1980s, the financial sector were an important component of various structural reforms aimed at reducing direct government intervention and creating a market-based economy directed by private sector (the restructuring of the commercial banking system in 1987, the liberalization of interest rate in 1987, the full convertibility of the Tunisian dinars for foreign investment and partial convertibility for transaction on the current account in 1993, the establishment of interbank foreign exchange market in 1994,...). These reforms have probably caused an improvement in financial indicators. In fact, the ratio M2/GDP increased from 40.83\% in 1980 to $53.95 \%$ in 1989 and from $43.76 \%$ in 1998 to $66.36 \%$ in 2012 (Figure 9). Generally, a higher ratio of M2 to GDP indicates a greater financial performance. However, according to Demetriades and Luintel (1996, pp. 360), the growth of M2/GDP can express the extension of monetization rather than financial deepening. Besides, Khan and Senhadji (2000, pp. 5) argued that some countries may have a high ratio of money to GDP but their financial system is underdeveloped because money is used as a store of value in the absence of other more attractive alternatives. Investment activities were boosted: the ratio domestic credit to private sector by banks (\% of GDP) moved from $37.69 \%$ in 1980 to $72.1 \%$ in 2012 . A higher value of the ratio may be interpreted as a sign of more financial services and then an improvement in financial intermediation.

We use two measures of political stability: "political right" and "civil right" indexes. The political right index is based on three subcategories: Electoral Process, Political Pluralism and Participation and Functioning of the Government. The civil liberty index is based on Freedom of Expression and Belief, Associational and Organizational Rights, Rule of Law and Personal Autonomy and Individual Rights. Scale from 1 to 7, with lower values indicating a higher level of political right or civil liberty, so a higher political stability. Long labeled "Not Free" by Freedom House, Tunisia was upgraded to "Partly Free" after the revolution, its political rights rating improving from 7 to 3 and its civil liberties rating going from 5 to 4 .

As indicators of the availability of sufficiently qualified labor in host countries, we used the secondary school enrolment ratio. The enrollment rate secondary followed a regular trend between 1980-2012. It reached $92 \%$ in 2012 against $24.67 \%$ in 1980.

We consider urban population ( $\%$ of total population) because the importance of urbanization cannot be minimized. Over the past 33 years urban population (\% of total) in Tunisia reached a minimum of $50.57 \%$ in 1980 and a maximum of 66.53 in 2012 . However, more than onethird of the urban population lives in the Tunis, the capital.

Different data sources are used in this paper: United Nations Conference on Trade and Development database, Freedom House database, World Economic Outlook database, IMF World Economic Outlook database, IMF International Financial Statistics and World Bank's World Development Indicators (Table 1). 
Table 1: List and definition of variables

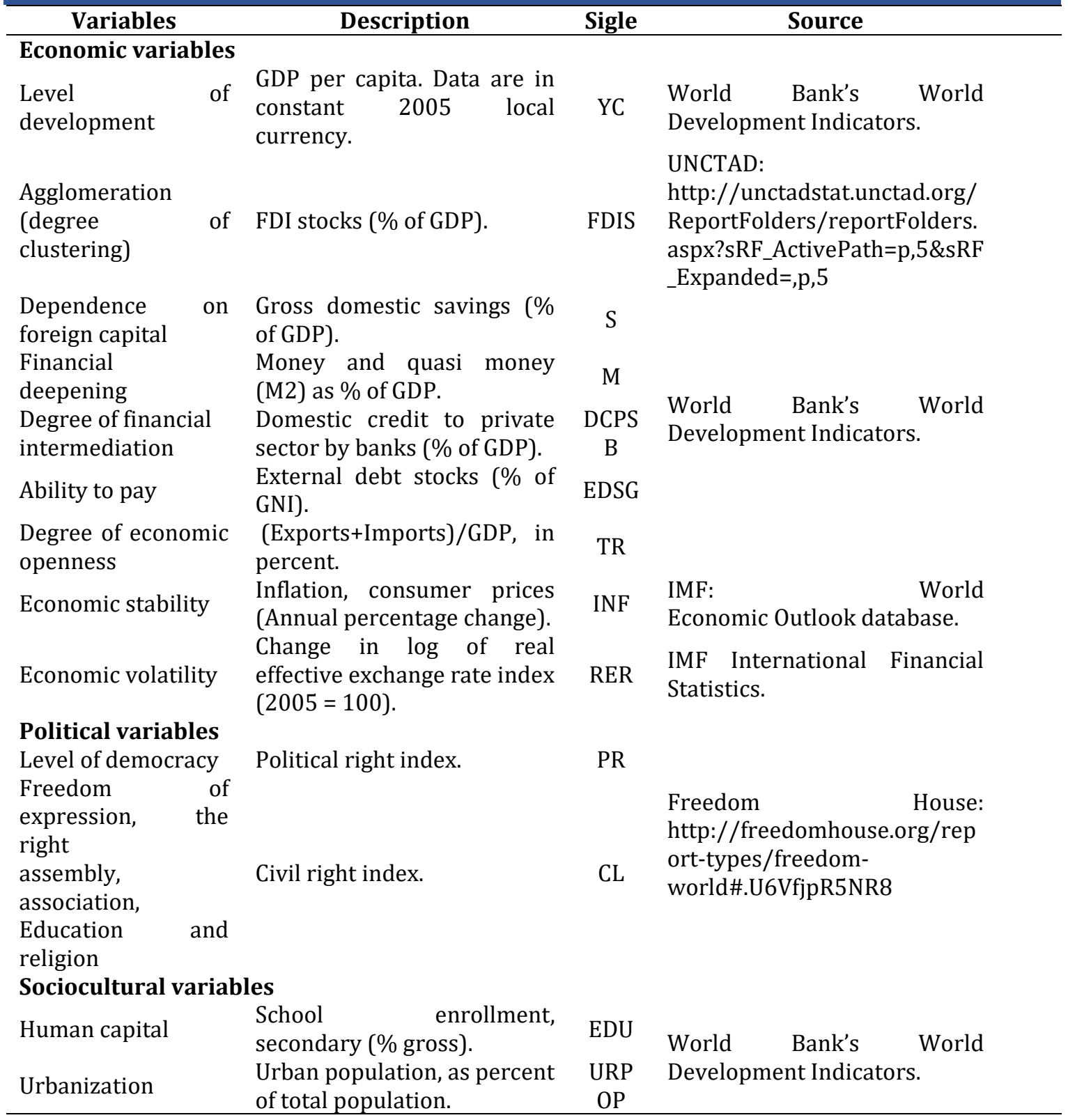

Our hypotheses might be written like this:

H1: A country with higher level of development will attract greater FDI inflows (Schneider and Frey, 1985; Cheng and Kwan, 2000; Wang and Swain, 1995; Cleeve, 2008; Mhlanga et al., 2010).

H2: FDI tends to cluster in particular locations (Wheeler and Mody, 1992; Barrell and Pain, 1999; Cheng and Kwang, 2000; Campos and Kinoshita, 2003; Walsh and Yu, 2010).

H3: The interrelations between FDI inflow, dependence on foreign capital and economic volatility are ambiguous (Froot \& Stein, 1991; Blonigen, 1995; Wang \& Swain, 1995; Blonigen \& Feenstra, 1996; Cleeve, 2008; Ben-Taher \& Giorgioni, 2009; Chaudhary et al., 2012; Chakrabarti, 2001; Thangamani et al., 2011).

H4: An insufficiently developed financial sector will deter FDI (Asiedu, 2002; Botrić \& Škuflić, 2006).

H5: A country with greater economic stability will attract greater FDI inflow (Buckley et al., 2007; Jadhav, 2012).

H6: The effect of trade openness on FDI is positive (Wheeler \& Moody, 1992; Asiedu, 2002; Cleeve, 2008; Ben-Taher \& Giorgioni, 2009; Mhlanga et al., 2010; Baklouti \& Boujelbene, 2014).

H7: Political instability will deter foreign direct investment inflows (Li \& Resnick, 2003; Busse, 2003; Pournarakis \& Varsakelis, 2004; Jakobsen \& de Soysa, 2006; Haksoon, 2010).

H8: A country with higher level of educated workforce is likely to attract greater foreign direct investment (Wei, 2005; Moosa, 2006; Cleeve, 2008; Blonigen et al., 2007; Rodriguez \& Pallas, 2008; Al-Sadig, 2009; Behname, 2013). 
H9: A positive relationship between urbanization and FDI inflows (Blonigen et al., 2007; Poelhekke \& Van Der-Ploeg, 2008; Anyanwu, 2012; Behname, 2013).

\section{Methodology}

In order to assess the validity of our hypothesis, the methodology used is the autoregressive distributed lag (ARDL) approach for estimation (or bounds testing cointegration procedure), proposed by Pesaran et al. (2001). The procedure is adopted for three reasons. First, it does not impose strict exogeneity assumption and allows for both stationary and non-stationary regressors (the bounds test allows both I(1) and I(0) variables as regressors, that is, the order of integration of appropriate variables may not necessarily be the same). Second, according to Harris and Sollis (2003), the ARDL approach leads to unbiased estimates of the long-run model. Thirdly, the test is relatively more efficient in small sample data size as is the case of our study.

Following Pesaran et al. (2001), we assemble the vector autoregression (VAR) of order $p$, denoted $\operatorname{VAR}(p)$, for the following growth function:

$$
Z_{t}=\mu+\sum_{i=1}^{p} \beta_{i} z_{t-i}+\varepsilon_{t}
$$

where $z_{t}$ is the vector of both $x_{t}$ and $y_{t}$, where $\mathrm{y}$ is the dependent variable defined as FDI, $x_{t}$ is the vector matrix which represents a set of explanatory variables. According to Pesaran et al. (2001), $y_{t}$ must be I(1) variable, but the regressor $x_{t}$ can be either I(0) or I(1). We further developed a vector error correction model (VECM) as follows:

$$
\Delta z_{t}=\mu+\alpha t+\lambda z_{t-1}+\sum_{i=1}^{p-i} \gamma_{t} \Delta y_{t-i}+\sum_{i=1}^{p-1} \gamma_{t} \Delta x_{t-i}+\varepsilon_{t}
$$

Where, $\Delta$ is the first-difference operator. The long-run multiplier matrix $\lambda$ as:

$$
\lambda=\left[\begin{array}{c}
\lambda_{Y Y} \lambda_{Y X} \\
\lambda_{X Y} \lambda_{X X}
\end{array}\right]
$$

The diagonal elements of the matrix are unrestricted, so the selected series can be either I(0) or I(1). If $\lambda_{Y Y}=0$, then $Y$ is I(1). In contrast, if $\lambda_{Y Y}<0$, then $Y$ is I(0).

The VECM procedures described above are imperative in the testing of at most one cointegrating vector between dependent variable $y_{t}$ and a set of regressors $x_{t}$. To derive model, we may follow the hypothesis made by Pesaran et al. (2001) in Case V: unrestricted intercept and unrestricted trend (we impose the restrictions $\lambda_{Y Y}=0, \mu \neq 0$ and $\alpha \neq 0$ ). The following unrestricted error correction model (ECM) is estimated:

$$
\Delta(F D I)_{t}=\beta_{0}+\beta_{1} \tau+\beta_{2} F D I_{t-1}+\beta_{3} X_{t-1}+\sum_{i=1}^{p} \beta_{4 i} \Delta(F D I)_{t-i}+\sum_{i=0}^{q} \beta_{5 i} \Delta(X)_{t-i}+\mu_{t}
$$

Where, $\Delta$ : the first-difference operator and ut is assumed to be normally distributed and white noise.

$X \in\{$ YC, FDIS, S, M, DCPSB, EDSG, TR, INF, RER, PR, CL, EDU, URPOP $\} . \quad$ The $\quad$ ARDL approach is based on the assumption that the variables are $\mathrm{I}(0)$ or I(1).

Equation (3) also can be considered as an ARDL of order $(p, q, r)$. It indicates that FDI inflow tends to be influenced and explained by its past values. The structural lags are established by using minimum Akaike's information criteria (AIC). From the estimation of ECMs, the long-run elasticities are the coefficient of one lagged explanatory variable (multiplied by a negative sign) divided by the coefficient of one lagged dependent variable (Bardsen, 1989). For example, in equation (3), the long-run inequality, $\mathrm{X}$ and FDI elasticities are $(\beta 3 /(-\beta 2))$. The short-run effects are captured by the coefficients of the first-differenced variables in equation (3).

After regression of equation (3), the Wald test (F-statistic) was computed to differentiate the long-run relationship between the concerned variables. The Wald test can be carry out by imposing restrictions on the estimated long-run coefficients of economic growth, inequality, investment and public expenditure. The null and alternative hypotheses are as follows:

$$
H_{0}: \beta_{2}=\beta_{3}=0: \text { (no long-run relationship) }
$$

Against the alternative hypothesis

$$
H_{1}: \neq \beta_{2} \neq \beta_{3} \neq 0 \quad \text { (a long-run relationship exists) }
$$


Given a relatively small sample size in this study, the critical values used are as reported by Narayan (2004) which based on small simple size between 30 and 80. According to these authors, the lower bound critical values supposed that the explanatory variables $X_{t}$ are integrated of order zero, or I(0), while the upper bound critical values assumed that $X_{t}$ are integrated of order one, or I(1). Therefore, if the computed F-statistic is smaller than the lower bound value, then the null hypothesis is accepted, so there is no long-run relationship between FDI inflow and its determinants. On the contrary, if the computed F-statistic is greater than the upper bound value, then FDI inflow and its determinants share a long-run level relationship. On the other hand, if the computed F-statistic falls between the lower and upper bound values, then the results are indecisive.

Before estimating the equation, the following intermediate steps need to be carried out:

- Jarque \& Bera (1980) normality of distribution tests: The null hypothesis is of normality, and rejection of the hypothesis (because of a significant p-value) leads to the conclusion that the distribution from which the data came is non-normal (Table 2).

Table 2: Jacque-Bera tests for normality
\begin{tabular}{|l|c|c|}
\hline & Jacque-Bera & Probability \\
\hline FDI & 0.358 & 0.835 \\
\hline YC & 3.096 & 0.212 \\
\hline FDIS & 2.018 & 0.364 \\
\hline S & 34.753 & 0.000 \\
\hline M & 3.433 & 0.179 \\
\hline DCPSB & 1.474 & 0.478 \\
\hline EDSG & 0.802 & 0.669 \\
\hline TR & 0.052 & 0.974 \\
\hline INF & 0.485 & 0.784 \\
\hline RER & 2.368 & 0.306 \\
\hline PR & 60.142 & 0.000 \\
\hline CL & 127.074 & 0.000 \\
\hline EDU & 2.462 & 0.291 \\
\hline URPOP & 3.376 & 0.184 \\
\hline
\end{tabular}

P-value < 0 indicates that the null hypothesis: "the distribution is normal" is rejected. Critical value: 5.99.

Source: Author's computations.

All variables were transformed into natural logarithms.

- We can reject the hypothesis that S, PR and CL are normally distributed, but we cannot reject the hypothesis that FDI, YC, M, DCPSB, EDSG, TR, INF, RER, EDU and URPOP are normally distributed (Table 9). We may explain the non-normal distribution of the political variables by the fact that they change slowly over time.

- Unit root tests (in order to determine the order of integration of all variables): we consider the Augmented Dickey- Fuller (ADF) tests that test the null hypothesis of Unit Root against the alternative of stationary. They are performed using the sequential procedure outlined by Holden and Perman (1994). They were made with Rats procedure developed by Goerlich (1992). For the variables studied, we first test the level stationary of the series: we apply the most general model formulation, with a constant and trend included (model 1). If the null hypothesis is rejected, we stop there. If not, we remove the trend but remain the constant if it was significant in the first step (model 2). If not, we remove the trend and the constant (model 3). If the null hypothesis is rejected, we stop there. If the time series are not stationary, we therefore proceed to the differentiation of order 1 of the series and we adopt the same procedure.

$$
\begin{gathered}
\text { Model 1: } L_{t}=\mu+\beta t+\sum_{i=1}^{k-1} \rho_{i} \Delta L_{t-i}+\alpha L_{t-1}+\varepsilon_{t} \\
\text { Model 2: } L_{t}=\mu+\sum_{i=1}^{k-1} \rho_{i} \Delta L_{t-i}+\alpha L_{t-1}+\varepsilon_{t} \\
\text { Model } 3: L_{t}=\sum_{i=1}^{k-1} \rho_{i} \Delta L_{t-i}+\alpha L_{t-1}+\varepsilon_{t} \\
\text { Where, } \varepsilon_{t} \text { i.i.d.N }\left(0, \sigma_{\varepsilon}^{2}\right) .
\end{gathered}
$$




\section{$L \in\{$ IDE, YC, FDIS, S, M, DCPSB, EDSG, TR, INF, RER, PR, CL, EDU, URPOP $\}$}

Based on the result from tables 3 and 4, it could be observed that GDP per capita, foreign direct investment stock, gross domestic saving, M2/GDP, domestic credit to private sector, external debt stock, trade, inflation and political right index are stationary at first difference I(1) series. However, foreign direct investment, real exchange rate, civil right index, secondary school enrollment rate and urban population are stationary at level: I(0) series.

\begin{tabular}{|l|c|c|c|c|}
\hline Table 3: Test Statistics at the level for Unit Roots & Model 3 & $\begin{array}{c}\text { Order of } \\
\text { integration }\end{array}$ \\
\hline RER & Model 1 & Model 2 & & $\mathrm{I}(0)$ \\
\hline CL & & YES & & $\mathrm{I}(0)$ \\
\hline EDU & & YES & & $\mathrm{I}(0)$ \\
\hline URPOP & & YES & & $\mathrm{I}(0)$ \\
\hline
\end{tabular}

YES means that the model is retained. Critical values are less than test statistics at the level but critical values are greater than test statistics in the first difference for ADF test.

Source: Author's computations.

\begin{tabular}{l} 
Table 4. Test Statistics in the first difference for Unit Roots \\
\hline
\end{tabular}

YES means that the model is retained. Critical values are less than test statistics at the level but critical values are greater than test statistics in the first difference for ADF test.

Source: Author's computations.

We realize 5 regressions (Table 5).

Table 5: Variables considered in each regression
\begin{tabular}{|c|c|c|c|}
\hline R1 and R2 & R3 & R4 & R5 \\
\hline YC & CL & PR & EDSG \\
\hline FDIS & & & \\
\hline S & & & \\
\hline M & & & \\
\hline DCPSB & & & \\
\hline TR & & & \\
\hline INF & & & \\
\hline RER & & & \\
\hline EDU & & & \\
\hline URPOP & & & \\
\hline
\end{tabular}

\section{Empirical results}

The estimation of Equation (3) using the ARDL model is reported in Tables 6, 7, 8, 9 and 10. Exchange rate, urban population and Gross domestic savings do not significantly affect FDI inflow. We test the model Using Hendry's general-to-specific method to get parsimonious specification. We eliminate the variables which are not significant, except for the level variables and the trend. Numerous diagnostic tests are used to evaluate the robustness of the model such as BreuschGodfrey serial correlation LM test, Jacque-Bera normality test and Breusch-Pagan-Godfrey Heteroskedasticity Test. 
Additionally, we examine the stability of short-run and long-run coefficients. We use Brown et al. (1975) stability testing technique. The CUSUM test is based on the cumulative sum of recursive residuals based on first set of $n$ observations. It is updated recursively and is plotted against the break points. If the plots of CUSUM statistics stay within the critical bonds of $5 \%$ level of significance, the null hypothesis of all coefficients in the given regression are stable and cannot be rejected. The CUSUM plot to check the stability of short run and long run coefficients in the ARDL error correction model are given below in figures 1, 2, 3, 4 and 5. It shows that statistics CUSUM is within the critical bonds, indicating that all coefficients in the ARDL model are stable during the sample period in this paper.

According to Tables 6, 7, 8, 9 and 10, all the tests indicate that the model has the aspiration econometric properties: the outcomes are serially uncorrelated, normally distributed and homoskedastic. Consequently, we could make reliable interpretation. The Jarque-Bera normality tests suggest that the errors are normally distributed, accept for regression 3 (Table 8). "The power of the Jarque-Bera test is poor for distributions with short tails, especially if the shape is bimodal, sometimes the test is even biased" (Thadewald \& Buning, 2004).

\section{Table 6: Estimated Model Based on Equation (3): unrestricted intercept and unrestricted} trend (R1)

\begin{tabular}{|l|c|c|c|}
\hline \multicolumn{1}{|c|}{ Variable } & Coefficient & Std. Error & t-Statistic \\
\hline FDI(-1) & -0.716 & 0.151 & $-4.733^{* * *}$ \\
\hline EDU(-1) & -7.024 & 2.126 & $-3.303^{* * *}$ \\
\hline DCPSB(-1) & -2.283 & 1.265 & $-1.804^{*}$ \\
\hline INF(-1) & -1.240 & 0.436 & $-2.846^{* *}$ \\
\hline D(FDI(-2)) & 0.311 & 0.151 & $2.057^{*}$ \\
\hline D(EDU) & -7.610 & 3.312 & $-2.297^{* *}$ \\
\hline D(DCPSB(-2)) & -1.895 & 1.397 & -1.356 \\
\hline D(INF) & -0.293 & 0.3066 & 3.954 \\
\hline C & 35.76 & 10.778 & $3.467^{* * *}$ \\
\hline @TREND & 0.269 & 0.077 & \\
\hline
\end{tabular}

Model criteria / Goodness of Fit:

R-square = 0.699; Adjusted R-square = 0.564; Wald F-statistic: 7.302[0.0009] ${ }^{* * *}$.

\section{Diagnostic Checking:}

$\mathrm{JB}=0.115[0.944]$; Breusch-Godfrey Serial Correlation LM Test: $0.090[0.9136]$; Heteroskedasticity Test: Breusch-Pagan-Godfrey: 1.387[0.2580].

$* * *, * *$ and $*$ indicate significance at $0.01,0.05$ and 0.10 level respectively. Probability values are quoted in square brackets.

As suggested by Narayan (2004), since the observation are annual, we choose 2 as the maximum order of lags in the ARDL. The lag order selected by Akaike's Information Criterion (AIC).

Source: Author's computations.

\section{Figure 1: Plot of Cumulative Sum of Recursive Residuals}

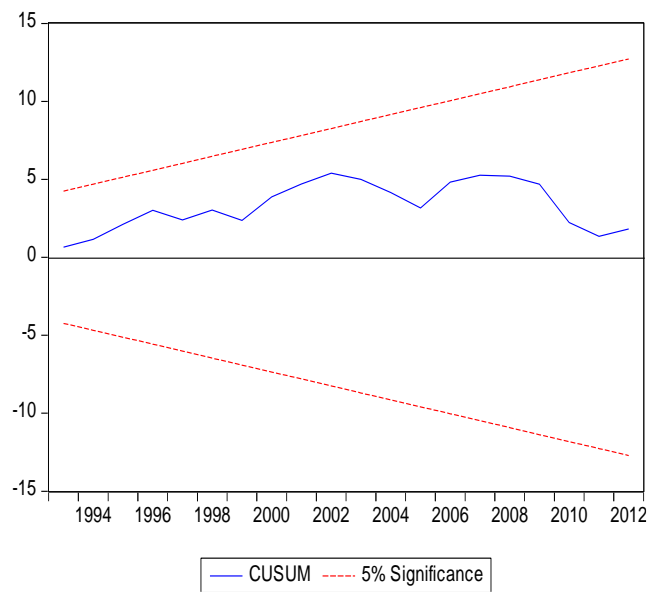

Source: Author's graph 
Table 7: Estimated Model Based on Equation (3): unrestricted intercept and unrestricted

\section{trend (R2)}

\begin{tabular}{|l|c|c|c|}
\hline \multicolumn{1}{|c|}{ Variable } & Coefficient & Std. Error & t-Statistic \\
\hline FDI $(-1)$ & -1.597 & 0.306 & $-5.218^{* * *}$ \\
\hline YC(-1) & 12.15 & 2.945 & $4.128^{* * *}$ \\
\hline $\mathrm{M}(-1)$ & -9.974 & 2.386 & $-4.178^{* * *}$ \\
\hline $\mathrm{TR}(-1)$ & 5.110 & 1.427 & $3.578^{* * *}$ \\
\hline $\mathrm{D}(\mathrm{YC}(-1))$ & -8.176 & 3.996 & $-2.045^{*}$ \\
\hline $\mathrm{D}(\mathrm{M})$ & -8.037 & 2.402 & $-3.345^{* * *}$ \\
\hline $\mathrm{D}(\mathrm{TR})$ & 4.002 & 1.301 & $3.074^{* * *}$ \\
\hline $\mathrm{D}(\mathrm{FDI}(-1))$ & 0.352 & 0.183 & $1.921^{*}$ \\
\hline $\mathrm{C}$ & -77.079 & 19.32 & $-3.989^{* * *}$ \\
\hline @TREND & -0.201 & 0.058 & $-3.428^{* * *}$ \\
\hline
\end{tabular}

Model criteria / Goodness of Fit:

R-square = 0.669; Adjusted R-square = 0.527; Wald F-statistic: 9.161[0.0004]***.

Diagnostic Checking:

$\mathrm{JB}=3.170[0.204]^{* * *}$; Breusch-Godfrey Serial Correlation LM Test: 0.580 [0.5693]; Heteroskedasticity Test: Breusch-Pagan-Godfrey: 0.877 [0.5594].

$* * *, * *$ and $*$ indicate significance at $0.01,0.05$ and 0.10 level respectively. Probability values are quoted in square brackets.

As suggested by Narayan (2004), since the observation are annual, we choose 2 as the maximum order of lags in the ARDL. The lag order selected by Akaike's Information Criterion (AIC).

Source: Author's computations.

\section{Figure 2: Plot of Cumulative Sum of Recursive Residuals}

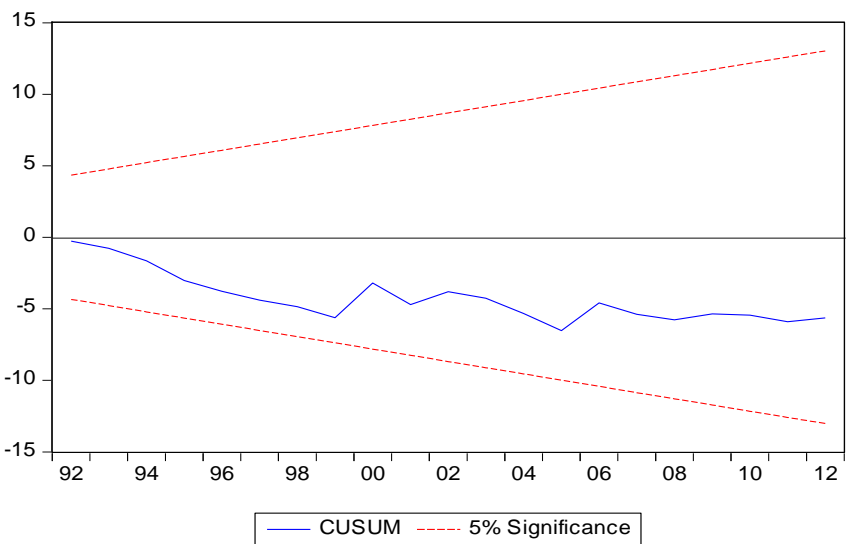

Source: Author's graph.

Table 8: Estimated Model Based on Equation (3): unrestricted intercept and unrestricted
trend (R3)
\begin{tabular}{|l|l|l|l|}
\hline Variable & Coefficient & Std. Error & t-Statistic \\
\hline FDI(-1) & -0.847 & 0.143 & $-5.914^{* * *}$ \\
\hline CL(-1) & 0.925 & 0.816 & 1.133 \\
\hline D(FDI(-2)) & 0.325 & 0.125 & $2.601^{* *}$ \\
\hline D(CL) & 1.643 & 0.738 & $2.225^{* *}$ \\
\hline D(CL(-2)) & 2.310 & 0.864 & $2.672^{* *}$ \\
\hline C & -1.464 & 1.263 & -1.158 \\
\hline @TREND & 0.039 & 0.009 & $4.341^{* * *}$ \\
\hline
\end{tabular}

Model criteria / Goodness of Fit:

R-square $=0.662 ;$ Adjusted R-square $=0.574 ;$ Wald F-statistic: $18.882[0.000]^{* * *}$.

Diagnostic Checking:

$\mathrm{JB}=21.529[0.000]^{* * *}$; Breusch-Godfrey Serial Correlation LM Test: 0.853 [0.4404]; Heteroskedasticity Test: Breusch-Pagan-Godfrey: 0.2767 [0.9421].

$* * *, * *$ and $*$ indicate significance at $0.01,0.05$ and 0.10 level respectively. Probability values are quoted in square brackets. 
As suggested by Narayan (2004), since the observation are annual, we choose 2 as the maximum order of lags in the ARDL. The lag order selected by Akaike's Information Criterion (AIC).

Source: Author's computations.

Figure 3: Plot of Cumulative Sum of Recursive Residuals

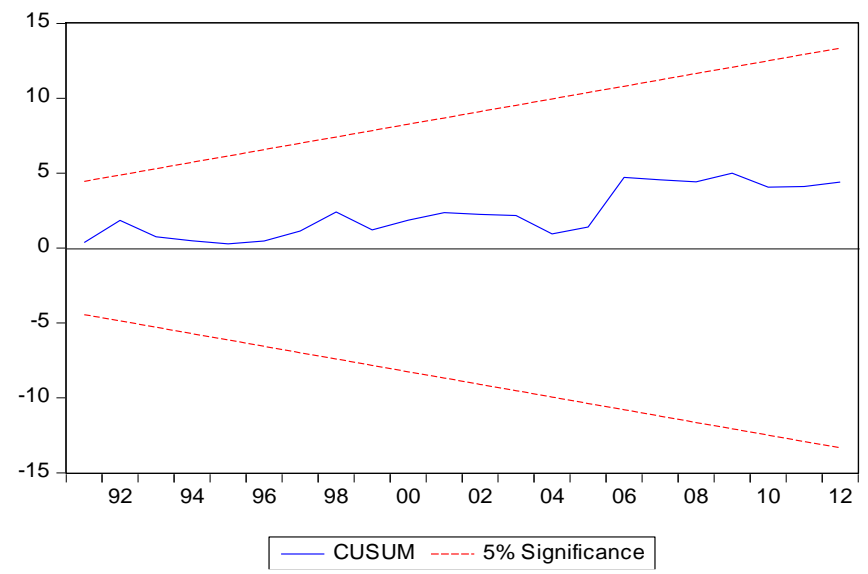

Source: Author's graph

Table 9: Estimated Model Based on Equation (3): unrestricted intercept and unrestricted
trend (R4)
\begin{tabular}{|l|c|c|c|}
\hline \multicolumn{1}{|c|}{ Variable } & Coefficient & Std. Error & t-Statistic \\
\hline FDI(-1) & -0.706 & 0.133 & $-5.296^{* * *}$ \\
PR(-1) & -3.206 & 1.117 & $-2.870^{* * *}$ \\
D(FDI(-2)) & 0.281 & 0.134 & $2.090^{* *}$ \\
D(PR(-1)) & 3.023 & 1.098 & $2.752^{* *}$ \\
C & 5.119 & 1.814 & $2.821^{* * *}$ \\
@TREND & 0.063 & 0.014 & $4.377^{* * *}$ \\
\hline
\end{tabular}

Model criteria / Goodness of Fit:

R-square = 0.610; Adjusted R-square = 0.529; Wald F-statistic: $16.363[0.000]^{* * *}$.

Diagnostic Checking:

$\mathrm{JB}=4.294$ [0.116]; Breusch-Godfrey Serial Correlation LM Test: 2.143 [0.1129]; Heteroskedasticity Test: Breusch-Pagan-Godfrey: 1.026 [0.4245].

$* * *, * *$ and $*$ indicate significance at $0.01,0.05$ and 0.10 level respectively. Probability values are quoted in square brackets.

As suggested by Narayan (2004), since the observation are annual, we choose 2 as the maximum order of lags in the ARDL. The lag order selected by Akaike's Information Criterion (AIC).

Source: Author's computations.

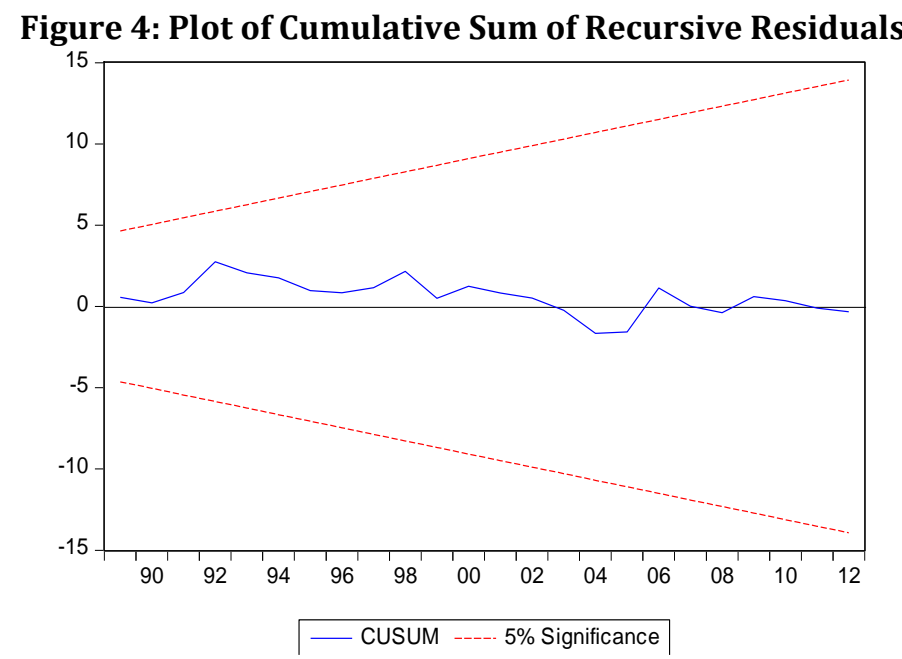

Source: Author's graph. 


\begin{tabular}{cccc} 
Table 10: Estimated Model Based on Equation (3): no intercept and unrestricted trend (R5) \\
Variable & Coefficient & Std. Error & t-Statistic \\
\hline FDI(-1) & -0.666 & 0.136 & $-4.887^{* * *}$ \\
EDSG(-1) & 0.010 & 0.041 & 0.252 \\
D(FDI(-2)) & 0.302 & 0.141 & $2.129^{* *}$ \\
D(EDSG(-2)) & -1.882 & 0.995 & $-1.890^{*}$ \\
@TREND & 0.028 & 0.010 & $2.766^{* *}$ \\
\hline
\end{tabular}

Model criteria / Goodness of Fit:

R-square $=0.541 ;$ Adjusted R-square $=0.4468$; Wald F-statistic: $11.949[0.0002]^{* *}$.

Diagnostic Checking:

$\mathrm{JB}=4.507$ [0.1050]; Breusch-Godfrey Serial Correlation LM Test: 1.0153 [0.3780];

Heteroskedasticity Test: Breusch-Pagan-Godfrey: 1.286 [0.3025].

$* * *, * *$ and $*$ indicate significance at $0.01,0.05$ and 0.10 level respectively. Probability values are quoted in square brackets.

As suggested by Narayan (2004), since the observation are annual, we choose 2 as the maximum order of lags in the ARDL. The lag order selected by Akaike's Information Criterion (AIC).

Source: Author's computations.

\section{Figure 5: Plot of Cumulative Sum of Recursive Residuals}

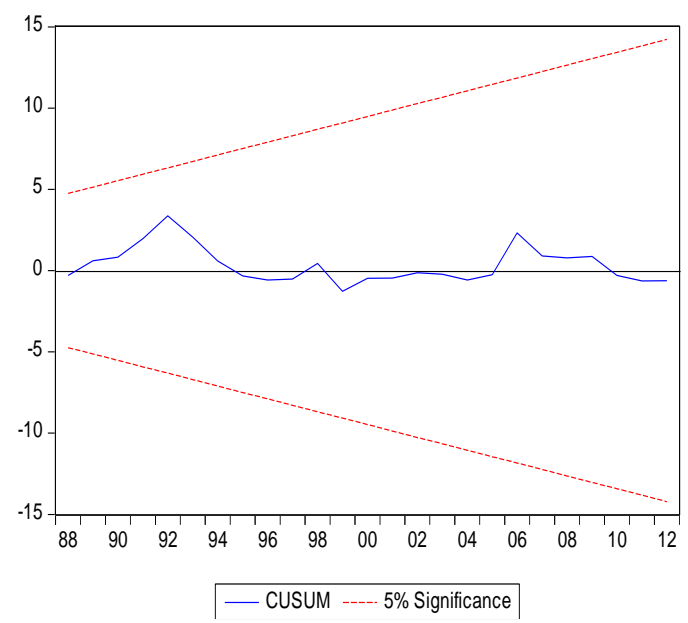

Source: Author's graph.

According to Table 11, there is a steady-state long-run relationship among FDI and macroeconomic environment (The null hypothesis is rejected at the $5 \%$ significance level. The computed F-statistics are generally greater than the lower critical bound and upper bound values, thus indicating the existence of a steady-state long-run relationship among FDI and macroeconomic environment).

\begin{tabular}{|} 
Table 11: Bounds Test for Cointegration Analysis \\
\hline Critical value 5\% & Lower Bound Value & Upper Bound Value \\
\hline R1 & 3.354 & 4.774 \\
R2 & 3.354 & 4.774 \\
R3 & 5.550 & 6.747 \\
R4 & 5.550 & 6.747 \\
R5 & 5.155 & 6.265 \\
\hline
\end{tabular}

Source: Author's computations.

Short and long run elasticities estimating effects of modeled explanatory variables on FDI inflow are examined. The goal is to verify the extent to which percentage change in specific independent variable impacts FDI inflow. Table 12 indicates that in the short run, education, domestic credit to private sector, inflation and political right index are negatively significantly on FDI inflow. This means that in the short run, 1 percent increase in education, domestic credit to private sector inflation and political right index will decrease FDI inflow by about 9.8, 0.32, 0.54 and 4.54 percent, respectively. Given the current situation of the country, we expect the current upward movement of the inflationary pressure to maintain its trend in the months ahead. The monetary 
authority would take necessary measures to mitigate those pressures. Besides that, in the long run, only education among these variables has show positively significant on FDI inflow. We may say that government should invest in human capital in short-run and the positive effect will appear in long-run. The education system is currently under attack for its inability to provide qualifications adapted to the labour market. The government should encourage the quality of human capital through improved education and improved skills training. Furthermore, in the short run, GDP per capita, M2/GDP (\%), trade and Civil right index have a positive impact on FDI inflow. The long-run and short-run results reveal that ability to pay has been a stimulant for FDI inflow. A high external debt stock would be signaling a good credit rating. The elasticity of GDP per capita is bigger in the short-run (7.608) than in the long-run (1.6) indicating the urgent need for a higher level of development in the short term to encourage FDI inflow. An unexpected result is that the effect of civil right index on FDI inflow is negative in the long-run. Unlike M2/GDP, the impact of trade on variation in FDI inflow is obvious: it still maintained its significant positive effect on FDI inflow in the long-run. Greater contribution in international trade by Tunisia could raise FDI inflows into the economy. The negative effects of political right index on FDI inflow is again established in the longrun. This implies a political environment where Level of democracy, Freedom of expression, the right assembly, association, education and religion are respected could promote FDI inflow. By contrast, domestic credit to private sector is not signed in a conventional manner: The elasticity in the long-run is negative, consistent with the short-run findings. We may say that credit rationing to the private sector over the years has not been able to stimulate FDI inflow because it would be interpreted by foreign investors as a sign of low confidence for success in the local market made by commercial banks, so there is a risk of doing FDI in Tunisia.

\begin{tabular}{|c|c|c|c|c|c|c|c|}
\hline $\mathbf{R 1}$ & $\operatorname{EDU}(-1)$ & $\operatorname{DCPSB}(-1)$ & $\operatorname{INF}(-1)$ & D(FDI(-2)) & D(EDU) & $\begin{array}{c}\text { D(DCPSB(- } \\
2))\end{array}$ & D(INF) \\
\hline & $-9,810$ & $-0,325$ & $-0,543$ & 0,251 & 24,469 & $-0,249$ & $-0,155$ \\
\hline \multirow[t]{2}{*}{ R2 } & YC(-1) & M(-1) & TR(-1) & $D(Y C(-1))$ & $\mathrm{D}(\mathrm{M})$ & D(TR) & D(FDI $(-1))$ \\
\hline & 7,608 & 0,821 & 0,512 & 1,600 & $-0,983$ & 0,498 & $-0,088$ \\
\hline R3 & $\begin{array}{c}\text { CL(-1) } \\
1,092\end{array}$ & $\begin{array}{c}\text { D(FDI(-2)) } \\
-0,351\end{array}$ & $\begin{array}{l}\mathbf{D}(\mathbf{C L}) \\
-5,055\end{array}$ & $\begin{array}{c}\mathbf{D}(\mathbf{C L}(-2)) \\
-1,406\end{array}$ & $\begin{array}{c}\mathbf{C} \\
0,634\end{array}$ & $\begin{array}{c}\text { @TREND } \\
0,027\end{array}$ & \\
\hline R4 & $\begin{array}{c}\text { PR(-1) } \\
-4,541\end{array}$ & $\begin{array}{c}\text { D(FDI }(-2)) \\
0,088\end{array}$ & $\begin{array}{c}\text { D(PR(-1)) } \\
-10,758\end{array}$ & $\begin{array}{c}\mathbf{C} \\
-1,693\end{array}$ & $\begin{array}{c}\text { @TREND } \\
-0,012\end{array}$ & & \\
\hline \multirow[t]{2}{*}{ R5 } & EDSG(-1) & D(FDI(-2)) & $\begin{array}{c}\text { D(EDSG(- } \\
2))\end{array}$ & @TREND & & & \\
\hline & 0,015 & $-30,200$ & 6,232 & 0,015 & & & \\
\hline
\end{tabular}

Source: Author's computations.

\section{Conclusion and Policy Implications}

This paper examined the relationship between macroeconomic environment and FDI inflow for Tunisia over the period 1980-2012. The results show that most of the determinants explain the variation in FDI inflow, as expected by theory. The interrelations between FDI inflow, education, M2/GDP and civil right index are ambiguous. Besides, no significant impact of exchange rate, urban population and government saving on variation in FDI inflow is found in general. These results suggest that Tunisia should undertake numerous reforms with clear objectives. Policy initiatives should shift towards trade liberalization, reforming its educational and financial system, mitigating inflationary pressure,....

Unfortunately, in our context, we don't consider some factors like governance and business environment because this will lead to a steep decline in the number of observations.

The research design for this research question is a comparative case study between Tunisia and the others MENA countries.

\section{Appendix A. Supplementary material}

Supplementary data associated with this article can be found, in the online version, at http://dx.doi.org/10.14254/jems.2017.2-1.4

\section{Funding}

The authors received no direct funding for this research. 


\section{Citation information}

Ghak, T., Zribi, A., Zrelli, N., \& Temmi, H. (2017). Determinants of foreign direct investment in Tunisia: Empirical assessment based on an application of the autoregressive distributed Lag model. Economics, Management and Sustainability, 2(1), 43-59. doi:10.14254/jems.2017.2-1.4

\section{References}

Agarwal, J.P. (1980). Determinants of Foreign Direct Investment: A Survey. Weltwirtschaftliches Archive, 116, 739-773.

Aharoni, Y. (1966). The Foreign Investment Decision Process. Boston, MA: Harvard University Press.

Aliber, R.Z. 1971. The Multinational Enterprise in a Multi currency World. In Dunning JH (ed.) The MultinationalEnterprise, (Allen ? Unwin: London).

Al-Sadig, A. (2009). The Effects of Corruption on FDI Inflows. Cato Journal, 29(2) Spring/Sumner.

Anyanwu, J.C. (2012). Why Does Foreign Direct Investment Go Where It Goes?: New Evidence From African Countries. Annals of Economics and Finance, 13(2), 425-462.

Asiedu, E. (2002). On the Determinants of Foreign Direct Investment to Developing Countries: Is Africa Different?. World Development, 30(1), 107-119.

Azam, M., \& Lukman, L. (2008). Determinants of Foreign Direct Investment in India, Indonesia and Pakistan: A Quantitative Approach. Journal of Managerial Sciences, IV(1). http://www.qurtuba.edu.pk/jms/default_files/JMS/4_1/02_azam.pdf

Baklouti, N., \& Boujelbene, Y. (2014). Impact of Institutional Quality on the Attractiveness of Foreign Direct Investment. Journal of Behavioural Economics, Finance, Entrepreneurship. Accounting and Transport, 2(4), 89-93. http://pubs.sciepub.com/jbe/2/4/2/

Barrell, R., \& Pain, N. (1999). Domestic institutions, agglomerations and foreign direct investment in Europe. European Economic Review, 43(4-6), 925-934.

Behname, M. (2013). FDI Localization, Wage and Urbanization in Central Europe. Comparative study of the evolution of stock returns for listed. Romanian Economic Journal, 16(48), 23-36.

Ben-Taher, G. (2009). The Determinants of Foreign Direct Investment: A Panel Data Study on AMU Countries. Center of International Banking, Economics, and Finance Working paper, November.

Blonigen, B.A, Davies, R.B., Waddell, G.R., \& Naughton, H. (2007). FDI in Space: Spatial Autoregressive Relationships in Foreign Direct Investment. European Economic Review, 51(5), 1303-1325.

Blonigen, B.A. (2005). A Review of the Empirical Literature on FDI Determinants. Atlantic Economic Journal, 33, 383-403.

Blonigen, B.A. 1995. Explaining Japanese Foreign Direct Investment in the United States. Unpublished Ph. D. Dissertation, University of California, Davis.

Blonigen, B.A., \& Feenstra, R.C. (1996). Effect of U.S. Trade Protection and Promotion Policies. National Bureau of Economic Research, Working Paper No 5285.

Botrić, V., \& Škuflić, L. (2006). Main determinants of foreign direct investment in the southeast European countries. Transition Studies Review, 13(2), 359-377.

Brown, R.L., Durbin, J., Evans, J.M. (1975). Techniques for Testing the Constancy of Regression Relations Over Time. Journal of the Royal Statistical Society, Series B, 37, 149-163.

Buckley, P.J., Clegg, L.J., Cross, A.R., Liu, X., Voss, H., \& Zheng, P. (2007). The Determinants of Chinese Outward Foreign Direct Investment. Journal of International Business Studies, 38(4), 499-518.

Busse, M. (2002). Democracy and FDI. HWWA Discussion Paper No. 220.

Campos, N., \& Kinoshita, Y. (2003). Why Does FDI Go Where It Goes? New Evidence from the Transition Economy. IMF Working Paper 03/228 (Washington: International Monetary Fund).

Caves, R. (1971). International corporations: the industrial economics of foreign investment. Economica, 38(149), 1-27.

Chakarabarti, A. (2001). The Determinants of Foreign Direct Investment: Sensitivity Analyses of Cross-Country Regressions. Kyklos, 54(1), 89-113.

Chaudhary, G.M., Shah, S., \& Bagram, M. (2012). Do Exchange Rate Volatility Effects Foreign Direct Investment? Evidence from Selected Asian Economies. Journal of Basic and Applied Scientific Research,

$2(4)$, 3670-3681. http://www.textroad.com/pdf/JBASR/J.\%20Basic.\%20Appl.\%20Sci.\%20Res.,\%202(4)3670 -3681,\%202012.pdf

Cheng, L.K., \& Kwan, Y.K. (2000). What are the Determinants of the Location of Foreign Direct Investment? The Chinese Experience. Journal of International Economics, 51, 379-400. 
Cherkaoui, M., \& Naini, A. (2002). Trade Liberalization, Real Exchange Rate and Export Diversification in Selected North African Economies. Paper presented in the Eighth Annual Conference of ERF.

CIA world factbook estimates for 31 December 2013, available at https://www.cia.gov/library/publications/the-world-factbook/rankorder/2198rank.html

Cleeve, E. (2008). How effective are fiscal incentives to attract FDI to Sub-Saharan Africa?. The Journal of Developing Areas, 42(1), 135-153.

Cyert, R.M., \& March, J.G. (1963). A Behavioral Theory of the Firm. Englewood Cliffs.

De Mello, Jr., \& Luiz, R. (1997). Foreign direct investment in developing countries and growth: A selective survey. Journal of Development Studies, 34(1), 1-34.

Demetriades Panicos, O, \& Luintel, KB. (1996). Banking sector policies and financial development in Nepal. Oxford bulletin of economics and statistics, 58(2), 355-372.

Driss, S. (2007). L'attractivité des investissements directs étrangers industriels en Tunisie. Région et développement, 25, 137-156.

Dunning, J.D. (1981). Explaining the international direct investment position of countries toward a dynamic or development approach. Weltwirtschaftliches Archiv, 117, 30-64.

Dunning, J.D. (1988).The eclectic paradigm of international production: a restatement and some possible extensions. Journal of International Business studies, 19(1), 1-31.

Dunning, J.H. (2001). The eclectic (OLI) paradigm of international production: past, present and future. International Journal of the Economics of Business, 8(2), 173-190.

Eltayeb, MS., \& Sidiropoulos, MG. (2010). Another look at the determinants of Foreign Direct Investment in MENA Countries: An Empirical Investigation. Journal of Economic Development, 35(12), 75-95. http://www.jed.or.kr/full-text/35-2/5.pdf

Faeth, I. (2009). Determinants of foreign direct investment - a tale of nine theoretical models. Journal of Economic Surveys, 23(1), 165-196.

Fanizza, D, Laframboise, N, Martin, E, Sab, R, \& Karpowicz, I. (2002). Tunisia's Experience with Real Exchange Rate Targeting and the Transition to a Flexible Exchange Rate Regime. IMF Working Paper WP/02/190.

Francis, J, Zheng C, \& Mukherji, A. (2009). An institutional perspective on foreign direct investment: A multi-level framework. Management International Review, 49(5), 565-583.

Froot, KA., \& Stein, JC. (1991). Exchange Rates and Foreign Direct Investment: An Imperfect Capital Markets Approach. Quarterly Journal of Economics, 106(4), 1191-1217.

Goerlich (1992). Available from www.estima.com.

Graham, E.M. (1978). Transatlantic investment by multinational firms: a rivalistic phenomenon?. Journal of Post Keynesian Economics, 1, 82-99.

Gwenhamo, F. (2009). Foreign Direct Investment in Zimbabwe: The Role of Institutional Factors. Working Paper Number 144.

Haksoon, K. (2010). Political Stability and Foreign Direct Investment. International Journal of Economics and Finance, 2(3), 59-71. http://citeseerx.ist.psu.edu/viewdoc/download;jsessionid=E6EF7DBBB2D99798C3173446 88207ECE?doi=10.1.1.677.1261\&rep=rep1\&type=pdf

Harris, R., \& Sollis, R. (2003). Applied time series modeling and forecasting. Wiley, West Sussex.

Helpman, E. (1984). A simple theory of international trade with multinational corporations. Journal of Political Economy, 92(3), 451-471.

Hisarciklilar, M., Kayam, S.S., \& Kayalica, O. (2006). Locational Drivers of FDI in MENA Countries: a spatial Attempt. Working Paper, Munich Personal RePEc Archive (MPRA), 1-20.

Holden, D., \& Perman, R. (1995). Unit Roots and Cointegration for the Economist. chap. 3, 47-112. In Rao; Cointégration for the Applied Economist. 2ème édition, 256.

Hymer, S.H. (1976). The International Operations of National Firms: A Study of Direct Investment. Cambridge, MA: MIT Press.

Iversen, C. (1935). Aspects of International Capital Movements. (Levin and Munksgaard: London, Copenhagen).

Jabri, A., Khaled, G., \& Ilyes, A. (2013). Determinants Of Foreign Direct Investment In MENA Region: Panel Co-Integration Analysis. The Journal of Applied Business Research, 29(4), 1104-1110.

Jadhav, P. (2012). Determinants of foreign direct investment in BRICS economies: Analysis of economic, institutional and political factor. Journal of Social and Behavioral Sciences, 37, 5-14. http://www.sciencedirect.com/science/article/pii/S1877042812007495

Jakobsen, Jo, \& de Soysa, I. (2006). Do foreign investors punish democracy? Theory and empirics, 1984-2001. Kyklos, 59(3), 383-410.

Kamaly, A. (2002). Evaluation of FDI Flows into the MENA Region. Economic Department, the American University in Cairo, 1-22. 
Karry, Z., \& Toumi, S. (2007). Investissement Direct Étranger et Attractivité Appréciation et enjeux pour la Tunisie. Revue d'Economie Urbaine et Régionale, 3, 479 - 501.

Kemp, P. (1964). Foreign Direct Investment and Economic Growth in Developing Countries: How Relevant are Host country and Industry characteristics?. Kiel working paper no. 1176.

Khan, S.M., \& Senhadji, S. (2000). Financial Development and Economic Growth: An Overview. IMF Working Paper wp/00/209.

Kindleberger, C.P. (1969). American Business Abroad: Six Lectures on Foreign Direct Investment. New Haven, CT: Yale University Press.

Knickerbocker, F.T. (1973). Ologopolistic Reaction and the Multinational Enterprise. Harvard University Press: Cambridge.

Kok, R., \& Ersoy, A.B. (2009). Analyses of FDI determinants in developing countries. International Journal of Social Economics, 36(1/2), 105-123.

La Porta, R., Lopez-de-Silanes, F., Schleifer, A., \& Vishny, R. (1998). Law and Finance. Journal of Political Economy, 106, 1113-1155.

Lahimer, N. (2006). Investissements directs étrangers et développement en Tunisie : Analyse économétrique à partir du concept du circuit économique. Université Paris Dauphine, centre de recherche : EURISCO.

Li, Q., \& Resnick, A. (2003). Democratic Institutions and Foreign Direct Investment Inflows to Developing Countries. International Organization, 57(1), 175-211.

MacDougall, GDA. (1960). The Benefits and Costs of Private Investment from Abroad: A Theoretical Approach. Economic Record, 36, 13-35.

Markusen, JR. (1984). Multinationals, multi-plant economies, and the gains from trade. Journal of International Economics, 16(3-4), 205-226.

Méon, P., \& Sekkat, K. (2004). Does the Quality of Institutions Limit MENA Integration in the World Economy?. ULB Institutional Repository 2013/7360, ULB - Universite Libre de Bruxelles.

Mhlanga, N, Blalock, G, Christy, R. (2010). Understanding foreign direct investment in the southern African development community: an analysis based on project-level data. Agricultural Economics, 41(3-4), 337-347.

Moosa, I.A. (2002). Foreign Direct Investment: Theory, Evidence and Practice. London: Palgrave.

Mottaleb, K.A. (2007). Determinants of Foreign Direct Investment and Its Impact on Economic Growth in Developing Countries. Journal of Munich Personal RePEc Archive (MPRA) Paper 9457, 1-15.

Narayan, P.K. (2004). Reformulating Critical Values for the Bounds F-statistics Approach to Cointegration: An Application to the Tourism Demand Model for Fiji. Discussion Papers, Department of Economics, Monash University, Australia. https://www.researchgate.net/publication/268048533_Reformulating_Critical_Values_for_t he_Bounds_F-

_statistics_Approach_to_Cointegration_An_Application_to_the_Tourism_Demand_Model_for_F iji

Ohlin, B. (1971). Comercio interregional e internacional. Barcelona: Oikos (orig.1933).

Onyeiwu, S. (2003). Analysis of FDI flows to Developing countries: Is the MENA region different?. ERF 10th Annual Conference, December, Marocco.

Onyeiwu, S. (2008). Does Investment in Knowledge and Technology Spur "Optimal" FDI in the MENA Region? Evidence from Logit and Cross-Country Regressions. Proceedings of the African Economic Conference, 161-179.

Peng, M. (2009). Institutions, cultures and ethics. In Peng M (org.); Global Strategic Management. Cincinnati: South-Western Cengage Learning, 90-122.

Pesaran, M.H., Shin, Y., \& Smith, R.J. (2001). Bounds Testing Approaches to the Analysis of Level Relationships. Journal of Applied Econometrics, 16, 289-326.

Poelhekke, S., \& Van der Ploeg, F. (2008). Growth, Foreign Direct Investment and Urban Concentration: Unbundling Spatial Lags. DNB Working Papers 195, Netherlands Central Bank, Research Department.

Pournarakis, M., \& Varsakelis, N-C. (2004). Institutions, internationalization and FDI: the case of economies in transition. Transnational Corporations, 13(2).

Ricardo, D. (1817). Principles of political economy. In Saffra P (Ed.) (1951), The Works and Correspondence of David Ricardo 1, Cambridge University Press, London.

Rodríguez, X., \& Pallas, J. (2008). Determinants of Foreign Direct Investment in Spain. Applied Economics, 40, 2443-2450.

Schneider, F. \& Frey, B.S. (1985). Economic and political determinants of foreign direct investment. World Development, 13(2), 161-175. 
Sekkat, K., \& Véganzonès-Varoudakis, M-A. (2004). Trade and Foreign Exchange Liberalization, Investment Climate, and FDI in the MENA Countries. World Bank Working Paper Series no. 39.

Shamsuddin, A.F. (1994). Economic Determinants of Foreign Direct Investment in Less Developed Countries. The Pakistan Development Review, 33, 41-51. http://www.pide.org.pk/pdf/PDR/1994/Volume1/41-51.pdf

Shirazi, A., Rodrigues, G., \& Karnik, A. (2008). Determinants of Foreign Direct Investment in MENA countries: an empirical analysis. Retrieved from http://ro.uow.edu.au/cgi/viewcontent.cgi?article=1168\&context=dubaipaper

Smith, A. (1776). An Inquiry into the Nature and Causes of the Wealth of Nations. Edited by Cannan E, 1961 and reprinted by Methuen, London.

Thadewald, T., \& Buning, H. (2004). Jarque-Bera test and its competitors for testing normality - A power comparison. Discussion Paper Economics 2004/9, School of Business and Economics, Free University of Berlin.

Thangamani, B., Xu, C., \& Zhong, C. (2011). Determinants and Growth Effect of FDI in South Asian Economies: Evidence from a Panel Data Analysis. International Business Research, 4(1), 4350. http://www.ccsenet.org/journal/index.php/ibr/article/view/7483

Toumi, S. (2009). Facteurs d'attractivité des investissements directs étrangers en Tunisie. L'Actualité économique, 85(2), 209-237.

Walsh, J.P., \& Yu, J. (2010). Determinants of Foreign Direct Investment: A Sectoral and Institutional Approach. IMF Working Paper, WP/10/187, July.

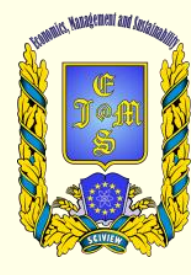

๑) 2016-2017, Economics, Management and Sustainability. All rights reserved. This open access article is distributed under a Creative Commons Attribution (CC-BY) 4.0 license.

You are free to:

Share - copy and redistribute the material in any medium or format Adapt - remix, transform, and build upon the material for any purpose, even commercially.

The licensor cannot revoke these freedoms as long as you follow the license terms.

Under the following terms:

Attribution - You must give appropriate credit, provide a link to the license, and indicate if changes were made.

You may do so in any reasonable manner, but not in any way that suggests the licensor endorses you or your use.

No additional restrictions

You may not apply legal terms or technological measures that legally restrict others from doing anything the license permits.

Economics, Management and Sustainability (ISSN: 2520-6303) is published by Scientific Publishing House "CSR",

Poland, EU and Scientific Publishing House "SciView", Poland

Publishing with JEMS ensures:

- Immediate, universal access to your article on publication

- High visibility and discoverability via the JEMS website

- Rapid publication

- Guaranteed legacy preservation of your article

- Discounts and waivers for authors in developing regions

Submit your manuscript to a JEMS at http://jems.sciview.net or submit.jems@sciview.net

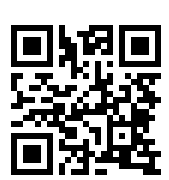

